\title{
Methane oxidation over alumina and ceria supported platinum
}

Elin Becker*, Per-Anders Carlsson and Magnus Skoglundh

Competence Centre for Catalysis and Department of Chemical and Biological Engineering, Chalmers University of Technology, SE-412 96 Göteborg, Sweden *Corresponding author: elin.becker@chalmers.se

\begin{abstract}
Oxidation of methane over $\mathrm{Pt} / \mathrm{Al}_{2} \mathrm{O}_{3}$ and $\mathrm{Pt} / \mathrm{CeO}_{2}$ catalysts was studied by transient gas-flow reactor and in situ FTIR spectroscopy experiments. The $\mathrm{Pt} / \mathrm{CeO}_{2}$ catalyst is more active, especially during oxygen pulsing, indicating a more efficient $\mathrm{CH}_{4}$ dissociation. This is likely thanks to less sensitivity towards oxygen poisoning due to higher oxygen storage capacity/mobility and/or additional sites in the $\mathrm{Pt} / \mathrm{CeO}_{2}$ system. Keywords: Environmental catalysis; periodic operation; FTIR spectroscopy; $\mathrm{CH}_{4}$; $\mathrm{Pt}$; $\mathrm{Al}_{2} \mathrm{O}_{3} ; \mathrm{CeO}_{2}$
\end{abstract}

\section{Introduction}

Methane produced from renewable sources, so-called biogas, can be used in vehicle applications originally designed for natural gas. Methane fuelled vehicles have, besides lower emissions of carbon dioxide, the advantages of low particulate and $\mathrm{NO}_{\mathrm{x}}$ emissions compared to vehicles with conventional diesel combustion engines [1]. Further, emerging advanced combustion concepts like homogeneous charge compression ignition $(\mathrm{HCCl})$ may produce exhausts with significant amounts of carbon monoxide and hydrocarbons, including methane [2-4]. In the mentioned applications, the exhaust temperature is considerably lower than in traditional combustion concepts, which generally is the case for upcoming energy efficient technologies. Thus, complete oxidation of methane at low temperatures is an important process.

Methane is significantly the most difficult hydrocarbon to oxidise catalytically. In practice, this is reflected by the relatively high temperatures $\left(>350^{\circ} \mathrm{C}\right)$ that are required for the catalytic oxidation to proceed efficiently, even on the most active catalysts like 
the noble metals, Pd, Pt and Rh. Methane is a special compound in the alkane series, containing only carbon-hydrogen bonds. The rate-determining step in the oxidation is the abstraction of the first hydrogen [5], here dissociation via adsorption [6]. At low temperatures, the oxidation of methane over $\mathrm{Pt}$ is problematic due to deactivation of the Pt crystallites by adsorbed oxygen [7]. This has been observed also for higher alkanes like propane [8]. The adsorbed oxygen decreases the ability of the catalyst surface to dissociate methane. The present objective is to understand the influence of oxygen on the activity for methane oxidation for Pt catalysts with different support materials. Pulse-response experiments and in situ DRIFT spectroscopy have been used to clarify reaction mechanisms.

\section{Experimental section}

\subsection{Catalyst preparation}

The supported platinum samples were prepared by impregnating alumina and ceria respectively with a halogen-free platinum precursor. The $\mathrm{Y}-\mathrm{Al}_{2} \mathrm{O}_{3}$ (Sasol, Puralox) was dispersed in distilled water and an aqueous solution of platinum(II)nitrate $\left(\mathrm{Pt}\left(\mathrm{NO}_{3}\right)_{2}\right.$ Heraeus $\mathrm{GmbH}$ ) was gently added to the alumina slurry under continuous stirring. The slurry was then instantly frozen with liquid nitrogen and freeze-dried. The resulting powder was calcined in air at $600^{\circ} \mathrm{C}$ for $2 \mathrm{~h}$, with a heating rate of $9.6^{\circ} \mathrm{C} / \mathrm{min}$ from 25 to $600^{\circ} \mathrm{C}$. For preparation of the $\mathrm{Pt} / \mathrm{CeO}_{2}$ sample, ceria (99.5 H.S.A. Rhône Poulenc) was impregnated with $\mathrm{Pt}$, using the same procedure as for the alumina sample. The resulting platinum load for both samples was $1 \mathrm{wt} .-\%$.

Monolith samples were prepared by immersing corderite monoliths (length $=15 \mathrm{~mm}$, $\mathrm{d}=12 \mathrm{~mm}, 400 \mathrm{cpsi}$ ) in water slurries containing either $\mathrm{Pt} / \mathrm{Al}_{2} \mathrm{O}_{3}$ and $\mathrm{Pt} / \mathrm{CeO}_{2}$ and respectively colloidal alumina sol (Disperal, Sasol) and ceria sol $\left(\mathrm{CeO}_{2}(\mathrm{Ac})\right.$, Nyacol) as binders. The monolith samples were thereafter dried at $90^{\circ} \mathrm{C}$ in air until all water had evaporated, and then calcined at $600^{\circ} \mathrm{C}$ for $5 \mathrm{~min}$. This procedure was repeated 
for both samples until $200 \mathrm{mg}$ of washcoat with a Pt load of $0.8 \mathrm{wt} . \%$ was attached to the samples. The samples were then calcined in air at $600^{\circ} \mathrm{C}$ for $2 \mathrm{~h}$.

\subsection{Flow-reactor experiments}

In brief, the continuous gas-flow reactor used for the methane oxidation experiments consists of a quartz tube wherein the sample was positioned [9]. Heating of the inlet gas and the sample occurred via resistive heating of a metal coil surrounding the tube. Both the inlet gas and the catalyst temperature were measured by separate thermocouples. Gases were introduced via individual mass flow controllers. The product stream was continuously analysed with a mass spectrometer (Balzers Quadstar 422) following the m/e ratios $2\left(\mathrm{H}_{2}\right), 15\left(\mathrm{CH}_{4}\right), 18\left(\mathrm{H}_{2} \mathrm{O}\right), 28(\mathrm{CO}), 32\left(\mathrm{O}_{2}\right) 40$ (Ar) and $44\left(\mathrm{CO}_{2}\right)$. Oxygen pulse response (PR) experiments were performed at different temperatures. The PR experiments were carried out by introducing 1250 vol.ppm of oxygen for 5 min to an otherwise constant flow of $500 \mathrm{ppm} \mathrm{CH}_{4} / \mathrm{Ar}$. In all experiments the total gas flow was $400 \mathrm{ml} / \mathrm{min}$, corresponding to GHSV=13,000 $\mathrm{h}^{1}$.

\subsection{In situ FTIR spectroscopy experiments}

The in situ spectroscopy experiments were performed in diffuse reflectance infrared Fourier Transform (DRIFT) mode using a Bio-Rad FTS6000 spectrometer equipped with a Harrick Praying Mantis DRIFT cell [10]. Gases were introduced to the reactor cell via individual mass flow controllers. A total flow of $100 \mathrm{ml} / \mathrm{min}$ was used in all experiments. The outlet gas composition was continuously analysed by a mass spectrometer. In the methane oxidation experiments, powder samples, $1 \% \mathrm{Pt} / \mathrm{Al}_{2} \mathrm{O}_{3}$ and $1 \% \mathrm{Pt} / \mathrm{CeO}_{2}$, were used. The samples were pre-treated first with oxygen and then hydrogen at $400^{\circ} \mathrm{C}$. The experiment was started by introducing a flow of $500 \mathrm{ppm}$ $\mathrm{CH}_{4} / \mathrm{Ar}$ to the reaction cell. After $40 \mathrm{~min}, 1250 \mathrm{ppm} \mathrm{O}$ was added to the $\mathrm{CH}_{4} / \mathrm{Ar}$ flow, resulting in a net-oxidising reaction mixture. After 50 min the $\mathrm{CH}_{4}$ flow was switched off, leaving a flow of $1250 \mathrm{ppm} \mathrm{O}_{2}$ over the sample. The presented spectra were 
collected at $400\left(\mathrm{Pt} / / \mathrm{Al}_{2} \mathrm{O}_{3}\right)$ and $350^{\circ} \mathrm{C}\left(\mathrm{Pt} / \mathrm{CeO}_{2}\right)$ and are shown as the difference between the measured spectrum and the corresponding background spectrum collected in Ar. A schematic illustration of the DRIFT spectroscopy experiments with collection points for the individual spectra is shown in Figure 1.

\section{Results}

Figure 2 shows results for oxidation of methane over the $\mathrm{Pt} / \mathrm{Al}_{2} \mathrm{O}_{3}$ (left panels) and $\mathrm{Pt} / \mathrm{CeO}_{2}$ (right panels) catalysts, during periodic variation of the gas composition between net-oxidising and net-reducing conditions. With the present reaction conditions, the $\mathrm{CH}_{4}$ conversion over the alumina-supported catalyst is generally low, while the ceria-supported catalyst shows a high conversion. Temporal increases in the activity for oxidation of methane upon a change in the gas composition are observed for both catalysts. Pulsing of oxygen has a significantly higher impact on the activity for methane oxidation for the $\mathrm{Pt} / \mathrm{CeO}_{2}$ catalyst than for $\mathrm{Pt} / \mathrm{Al}_{2} \mathrm{O}_{3}$. This is most likely due significant differences in sensitivity to oxygen poisoning between the samples. Comparing the results of the two catalysts in more detail, considerable differences in oxygen consumption and hydrogen production can be observed. For the ceriasupported catalyst, much more oxygen is consumed than is required for complete stoichiometric oxidation of $500 \mathrm{ppm} \mathrm{CH}_{4}$.

Figure 3 shows DRIFT spectra of $\mathrm{Pt} / \mathrm{Al}_{2} \mathrm{O}_{3}$ (left) and $\mathrm{Pt} / \mathrm{CeO}_{2}$ (right) exposed to the gas composition sequence shown in Figure 1. For the alumina-supported sample, adsorption of $\mathrm{CH}_{4}$ results in absorption bands at 2092, 2026 and $1780 \mathrm{~cm}^{-1}$ (spectrum A1) corresponding to linearly and bridge bonded $\mathrm{CO}$ adsorbed to Pt [11]. This indicates the presence of available oxygen, even though the sample was pre-reduced. The second spectrum (A2), recorded after 10 min with methane-oxygen reaction mixture, shows only a small peak at $2077 \mathrm{~cm}^{-1}$, indicating that most of the $\mathrm{CO}$ has been oxidised. Some changes in the lower wavenumber region $\left(1700-1000 \mathrm{~cm}^{-1}\right)$ usually assigned to OCO-stretching vibrations of carbonate and formate species on the 
support $[12,13]$, are observed here. Compared to $\mathrm{Pt}^{\mathrm{A}} \mathrm{Al}_{2} \mathrm{O}_{3}$ the absorption bands observed on the ceria-supported sample are generally much more intense, especially in the region below $1700 \mathrm{~cm}^{-1}$. Given the large number of overlapping absorption bands in this region, we here focus on analysing the main trends. The first spectrum (C1), recorded after $8 \mathrm{~min}$ of $\mathrm{CH}_{4}$ exposure, reveal absorption bands at 2100 and $2026 \mathrm{~cm}^{-}$ ${ }^{1}$ corresponding to $\mathrm{CO}$ adsorbed to different sites on Pt. Significant absorption bands are also observed in the $\mathrm{OH}$-stretching vibration region $\left(3300-4000 \mathrm{~cm}^{-1}\right)$ and even more so in the region below $1700 \mathrm{~cm}^{-1}$. After $20 \mathrm{~min}$ of $\mathrm{CH}_{4}$ exposure (C2), the $\mathrm{CO}-\mathrm{Pt}$ bands have shifted and increased in intensity. Changes have occurred also in the carbonate region, with a fourfold intensity increase of the absorption bands. Spectrum C3, recorded after 10 minutes with methane-oxygen reaction mixture, shows diminished CO-Pt bands, however, there is a remaining peak at $2100 \mathrm{~cm}^{-1}$.

\section{Discussion}

For the $\mathrm{Pt} / \mathrm{Al}_{2} \mathrm{O}_{3}$ catalyst, the low methane conversion in the flow-reactor experiment signifies oxygen poisoning of the catalyst. The higher activity for methane oxidation of the $\mathrm{Pt} / \mathrm{CeO}_{2}$ catalyst is likely more complex and a few mechanistic scenarios may be addressed. In the first scenario the ceria-supported catalyst is assumed to be less sensitive to oxygen poisoning due to the ability of ceria to buffer oxygen. When pulsing oxygen, the ceria may be partially reduced during the oxygen-free periods, and can thus store some of the excess oxygen during the lean periods. More vacant Pt sites are hereby available on the catalyst for methane adsorption. Thus, here it is likely that oxygen poisoning is prevented (or delayed) by spill-over of oxygen from the $\mathrm{Pt}$ to the ceria. It has previously been observed that carbonates form more easily on reduced compared to more oxidised ceria [14]. The intensity increase in the carbonate region (1700-1000 $\left.\mathrm{cm}^{-1}\right)$ supports reduction of ceria upon continued exposure to $\mathrm{CH}_{4}$. Further, the absorption band at $2124 \mathrm{~cm}^{-1}$ has been associated with $\mathrm{CO}$ adsorbed to $\mathrm{Ce}^{3+}[14]$. 
The intensity of the carbonate absorption bands decreases after the oxygen is switched on (spectrum C3). Although not presented here, the MS measurements show that the oxygen consumption is higher than required for stoichiometric oxidation of methane, in line with the PR experiments discussed above. This further supports that ceria can store some of the excess oxygen and that it is likely reduced by $\mathrm{CH}_{4}$ during oxygen-free periods.

Another scenario is that, in addition to the Pt-sites, other sites for methane dissociation are available on the $\mathrm{Pt} / \mathrm{CeO}_{2}$ catalyst, resulting in a higher $\mathrm{CH}_{4}$-oxidation activity. These sites may be located at the $\mathrm{Pt} / \mathrm{CeO}_{2}$ interface, or possibly even on the ceria surface itself. Probably, spill-over of the dissociated methane species from the support to the $\mathrm{Pt}$ or $\mathrm{Pt} /$ support interface may be required for further reaction into $\mathrm{CO}_{2}$ [15]. The more pronounced minimum in the methane outlet concentration when the oxygen is switched off (right panel of Figure 2) signifies that dissociative adsorption of methane proceeds considerably faster on $\mathrm{Pt} / \mathrm{CeO}_{2}$ compared to the alumina-supported catalyst. The more intense carbon-containing absorption bands on the ceria-supported sample also agree with this observation. Odier et al. [15], observed that surface carbonates are formed on a Pt-free ceria sample when exposed to methane, which supports the possibility that in the present study, dissociative adsorption of $\mathrm{CH}_{4}$ may occur on the ceria surface. The absorption bands corresponding to $\mathrm{CO}$ adsorbed to $\mathrm{Pt}$ appear at various wavenumbers, which indicates a number of different Pt-sites. The band at $2100 \mathrm{~cm}^{-1}$ possibly corresponds to CO adsorbed to partially oxidised $\mathrm{Pt}[16,17]$. This band is present in spectrum $\mathrm{C} 1$, but disappears with continued $\mathrm{CH}_{4}$ exposure $(\mathrm{C} 2)$. However, it reappears after the addition of oxygen (C3), which also indicates a transition between different oxidation states of the catalyst, likely involving both the $\mathrm{Pt}$ and the ceria.

\section{Concluding remarks}

This study shows that pulsing of oxygen has a considerably higher impact on the 
activity for methane oxidation on $\mathrm{Pt} / \mathrm{CeO}_{2}$ than on $\mathrm{Pt} / \mathrm{Al}_{2} \mathrm{O}_{3}$. This effect is likely due to that the ceria-supported catalyst is less sensitive to oxygen poisoning due to the ability of ceria to act as an oxygen buffer. When pulsing oxygen, the ceria may be partially reduced during the oxygen free periods, and can thus store some of the excess oxygen during the lean periods. More vacant sites are hereby available on the catalyst for methane adsorption. In addition, dissociative adsorption of methane appears to occur faster on $\mathrm{Pt} / \mathrm{CeO}_{2}$, which may be due to that $\mathrm{CH}_{4}$ can dissociate on the ceria surface, while for $\mathrm{Pt} / \mathrm{Al}_{2} \mathrm{O}_{3}$, the platinum is needed for dissociative adsorption. The significantly higher methane oxidation activity as a response to oxygen pulsing for the ceria supported Pt suggests that a potential strategy to achieve improved methane conversion over $\mathrm{Pt} / \mathrm{CeO}_{2}$ is to shorten the rich cycles and introduce longer lean pulses. In vehicle applications, this would also be beneficial with regard to fuel economy.

\section{Acknowledgements}

This work was performed within the Competence Centre for Catalysis, which is financially supported by Chalmers University of Technology, the Swedish Energy Agency and the member companies: AB Volvo, Volvo Car Corporation, Scania CV AB, GM Powertrain Sweden AB, Haldor Topsøe A/S and The Swedish Space Corporation.

\section{References}

[1] P. Gélin, L. Urfels, M. Primet and E. Tena, 83 (2003) 45.

[2] E.W. Kaiser, M.M. Maricq, N. Xu and J. Yang, SAE 2005-01-3749.

[3] S.A. Lewis, J.M.E Storey, B. Bunting and J.P. Szybist, SAE 2005-01-3737.

[4] M. Lemel, A. Hultqvist, A. Vressner, H. Nordgren, H. Persson and B. Johansson, SAE 2005-01-3724.

[5] R. Burch and M. J. Hayes, J. Mol. Catal. A 100 (1995) 13.

[6] S. Oh, P. Mitchell, R. Siewert, J. Catal. 132 (1991) 287.

[7] E. Becker, P.-A. Carlsson, H. Grönbeck and M. Skoglundh, J. Catal., 252 (2007) 11.

[8] P.-A. Carlsson, S. Mollner, K. Arnby and M. Skoglundh, Chem. Eng. Sci. 59 (2004) 4313.

[9] P.-A. Carlsson, E. Fridell and M. Skoglundh, Catal. Lett. 115 (2007) 1. 
[10] J. Jansson, A.E.C. Palmqvist, E. Fridell, M. Skoglundh, L. Österlund, P. Thormählen and V. Langer, J. Catal 211 (2002) 387.

[11] R.P.H. Gasser, An introduction to chemisorption and catalysis by metals, (Oxford University Press, Oxford, 1985).

[12] C. Li, Y. Sakata, T. Arai, K. Domen, K. Maruya and T. Oishi, J. Chem. Soc. Faraday. Trans., 85 (1989) 929.

[13] T. Shido and Y. Iwasawa, J. Catal 136 (1992) 493.

[14] F. Bozon-Verduraz and A. Bensalem, J. Chem. Soc. Faraday. Trans., 90 (1994) 653.

[15] E. Odier, Y. Shuurman and C. Mirodatos, Catal. Today, 127 (2007) 230.

[16] P.-A. Carlsson, L. Österlund, P. Thormählen, A. Palmqvist, E. Fridell, J. Jansson and M. Skoglundh, J. Catal 226 (2004) 422.

[17] M. Primet, J.M. Basset, M.V. Mathieu and M. Prettre, J. Catal 29 (1973) 213.

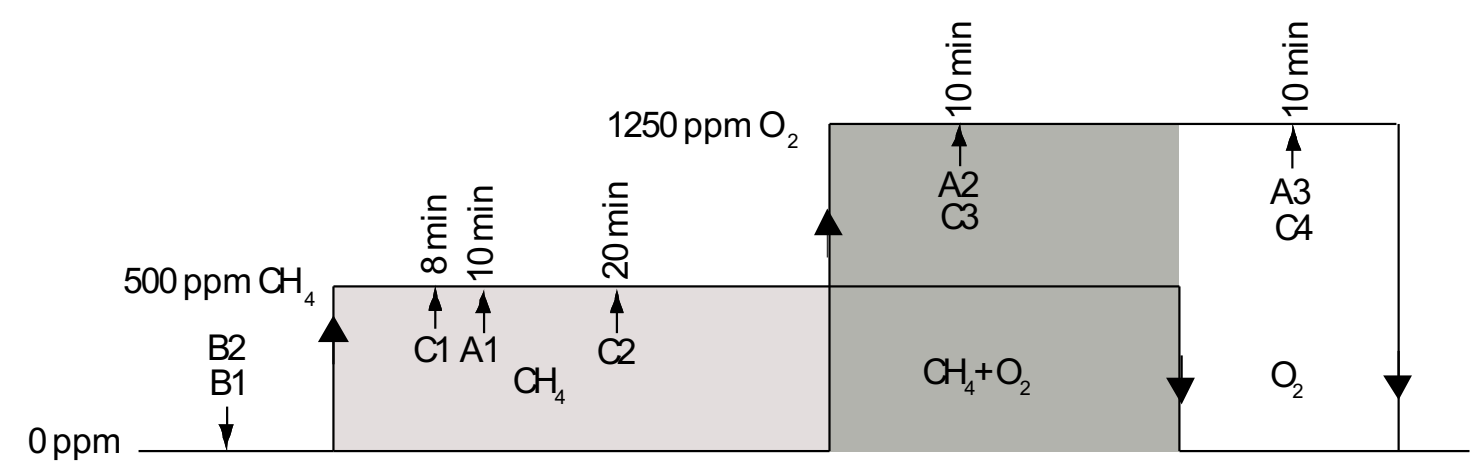

Figure 1. Schematic illustration of the DRIFT spectroscopy experiments showing the gas composition at the time of collection for each spectrum. The spectra (shown in Figure 3 ) have been denoted $\mathrm{A} 1-\mathrm{A} 3\left(\mathrm{Pt}_{\mathrm{Al}} \mathrm{O}_{3}\right.$ sample), $\mathrm{C} 1-\mathrm{C} 4\left(\mathrm{Pt} / \mathrm{CeO}_{2}\right.$ sample), $\mathrm{B} 1$ and $\mathrm{B} 2$ for the background spectra. The time refers to the time after a change in the gas composition. 

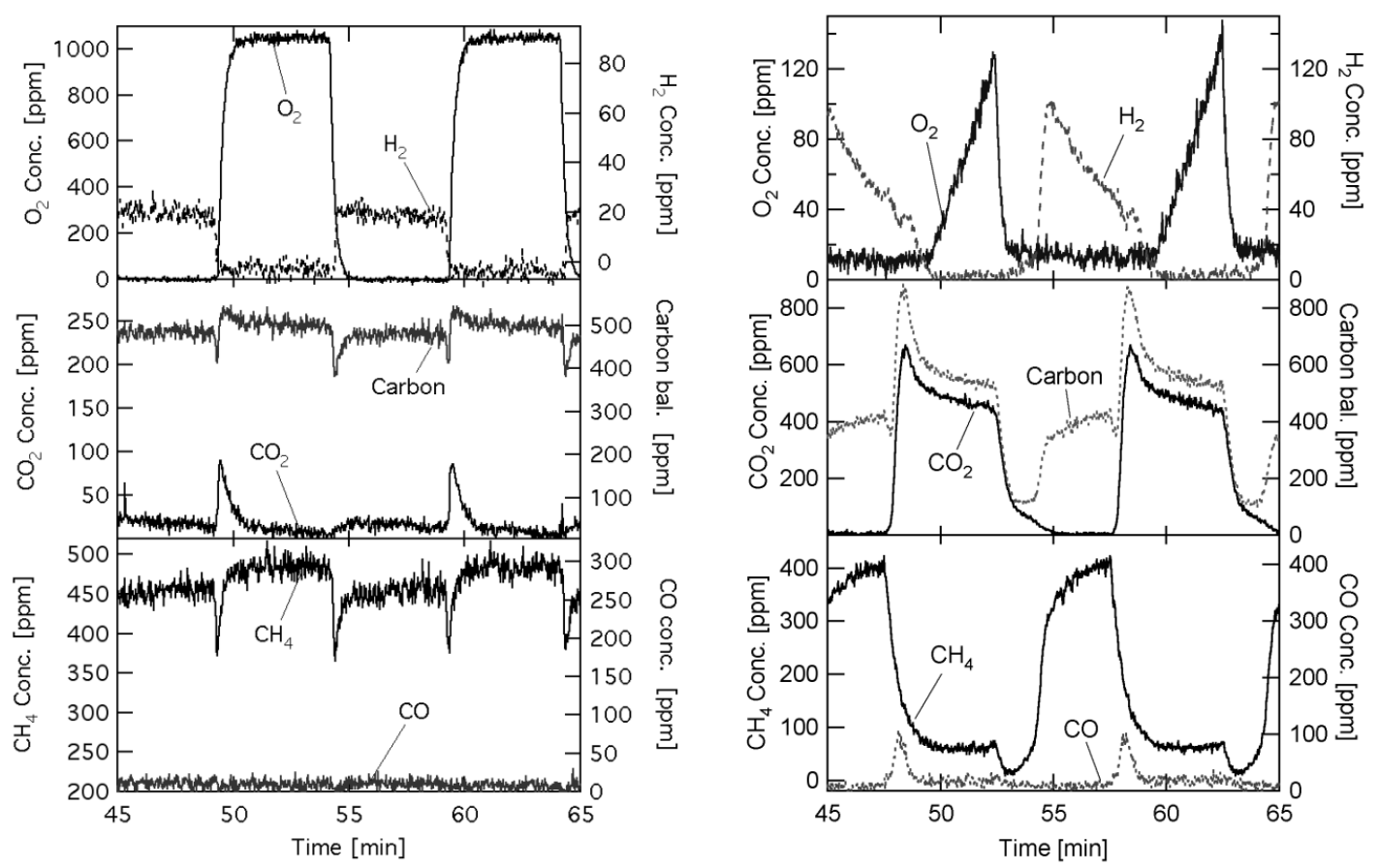

Figure 2. Oxidation of $500 \mathrm{ppm} \mathrm{CH}_{4}$ while varying the oxygen concentration between 1250 ppm for 5 minutes and $0 \mathrm{ppm}$ for five minutes at an inlet gas temperature of $350^{\circ} \mathrm{C}$ over

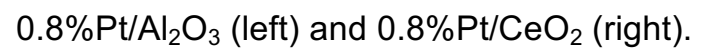
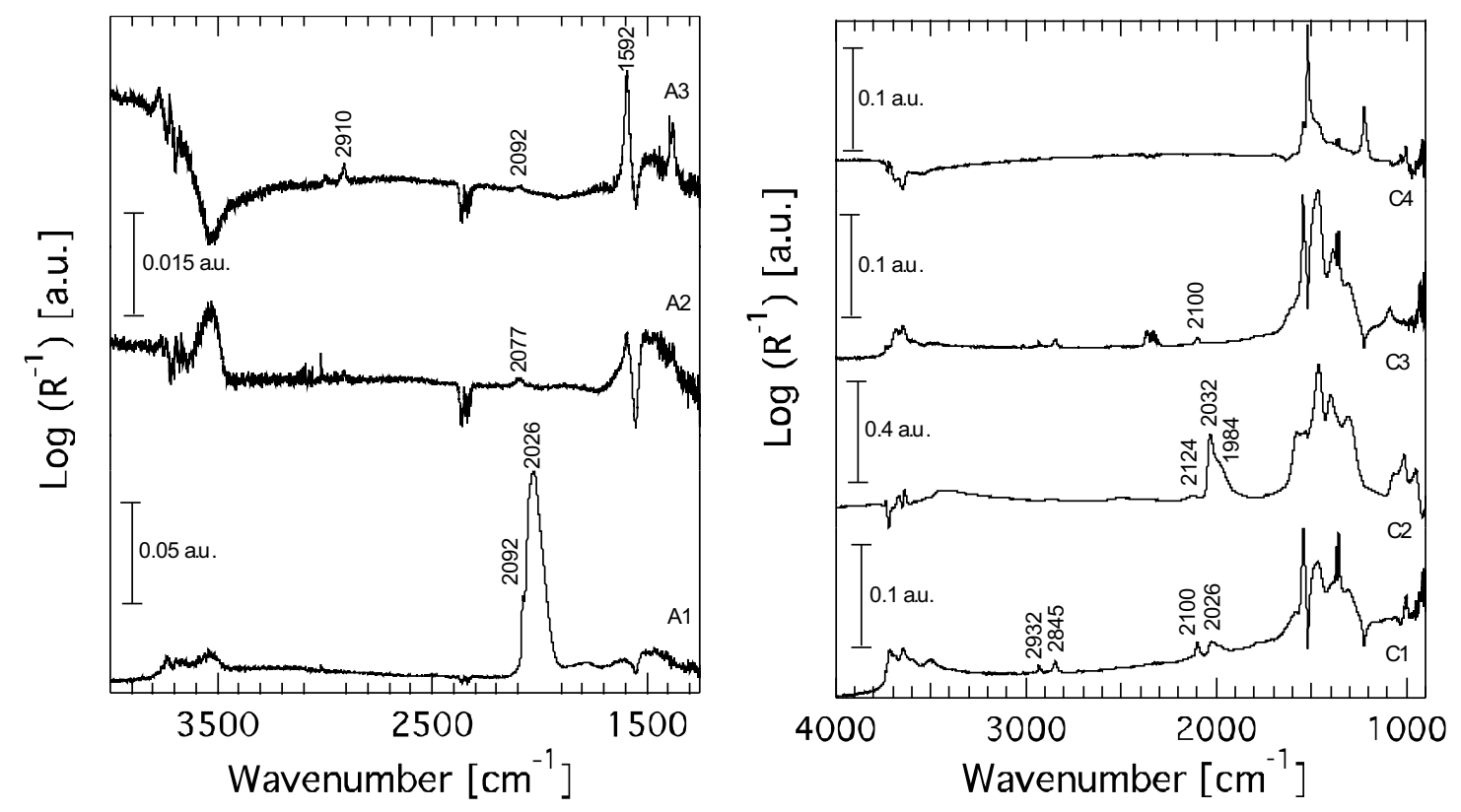

Figure 3. Left panel: DRIFT spectra of $\mathrm{Pt} / \mathrm{Al}_{2} \mathrm{O}_{3}$ at $400^{\circ} \mathrm{C}$ collected after 10 min of $\mathrm{CH}_{4}$ exposure (A1), 10 minutes after adding $1250 \mathrm{ppm} \mathrm{O}_{2}$ (A2) and $10 \mathrm{~min}$ after the $\mathrm{CH}_{4}$ flow is switched off (A3). Right panel: DRIFT spectra of $\mathrm{Pt} / \mathrm{CeO}_{2}$ at $350^{\circ} \mathrm{C}$ collected after 8 min of exposure to $500 \mathrm{ppm} \mathrm{CH}_{4}(\mathrm{C} 1)$, after $20 \mathrm{~min}$ of exposure to $500 \mathrm{ppm} \mathrm{CH}_{4}(\mathrm{C} 2), 10 \mathrm{~min}$ after adding $1250 \mathrm{ppm} \mathrm{O} 2$ to the $\mathrm{CH}_{4}$ flow (C3) and 10 min after the $\mathrm{CH}_{4}$ flow is switched off (C3). The spectral resolution was $1 \mathrm{~cm}^{-1}$. Note the vertical scale differences, especially for spectrum $\mathrm{A} 1$ and $\mathrm{C} 2$. 